\title{
CAUSES OF MASSIVE FAILURES AND REMEDIAL MEASURES FOR GROUNDWATER BOREHOLES: CASE EXAMPLES FROM SOUTHEASTERN NIGERIA
}

\author{
B. I. ODOH, H. N. EZEH, B.C.E. EGBOKA AND E. I. OKORO
}

(Received 7 August, 2007; Revision Accepted 5 November, 2008)

\begin{abstract}
A comprehensive inventory of 468 boreholes in different parts of southeastern Nigeria was made to determine the various causes of massive borehole failures in the hydrogeologic environment of the area and proffer appropriate remedial actions. The locations of these boreholes were visited. Out of the total boreholes visited, 258 of them were at optimal performance, 103 have a declining performance while 109 were not functioning. Borehole failures are indicated by excessive sand pumping, muddy water extraction and continuous decline in the performance capability and drawdown of the borehole. In this study, borehole failures are categorized into two major groups, namely: Pre syn Construction and Post Construction Failures. The first group deals with failures associated with poor/bad technology and anthropogenic services that may have been applied before and during the borehole construction while the later discusses failures resulting from gradual decline in the performance of the borehole over time as a result of over pumping and lack of proper maintenance culture. The causes of these failures are lack of proper groundwater studies and evaluation, poor planning and lack of foresight, bad technology and service delivery, lack of appropriate expertise, poor financial resources and corruption, over exploitation of groundwater by over-pumping, absence of well data and mechanical obstructions of well. Appropriate and specific remedial actions such as hydrogeological and geophysical studies to determine the quantity and quality of grouhdwater available before drilling a borehole. strate yic planning for effective implementation of the steps necessary for successful completion of a quality borehole and drawing up of effective maintenance culture are all recommended to reduce the rates of borehole failures in parts of Southeastern Nigeria. The recommendations outlined in the paper will assist significantly in addressing the challenges of borehole failures and will also contribute in better planning of future water well projects in the area
\end{abstract}

KEYWORDS: Aquifers, groundwater boreholes, well failures, gravel packing, pumping test analysis, well casing/development, and geochemical parameters

\section{INTRODUCTION}

Groundwater is an essential and vital resource for various livelihoods in homes, commerce, industry, agriculture etc. in all nations. A number of factors can affect the quality of a water resources infrastructure. Borehole performance is influenced by several factors, including the nature of the aquifer from which the groundwater is being extracted, the method of construction, the nature of well screen used in the well, the diameter of the borehole, the pumping rate, and the maintenance culture associated with the management of the borehole. People may often think of a borehole as having unlimited capacity and in relative terms where borehole installation was properly-done, such boreholes do approach the desired performance (Egboka, 1999 and Robert, 2005). This study aimed to finding the various causes of borehole failures in parts of Southeastern Nigeria with the target to proffering lasting solutions to the challenges. Fig. 1 show the geology and the location of the failed boreholes studied in parts of southeastern Nigeria

B. I. Odoh, Department of Geology and Exploration Geophysics, Ebonyi State University, P M B 053, Abakaliki, Ebonyi State. Nigeria

H. N. Ezoh, Department of Geology and Exploration Geophysics. Ebonyi State Unıversity, P.M B 053 Abakalikı, Ebonyi State. Nigeria

B.C.E. Egboka, Department of Geological Sciences, Nnamdi Azikiwe University P.M.B 5025, Awka. Anambra State. Nigeria

E. I. Okoro, Department of Geological Sciences, Nnamdi Azikiwe University, P.M B 5025, Awka, Anambra State, Nigeria. 


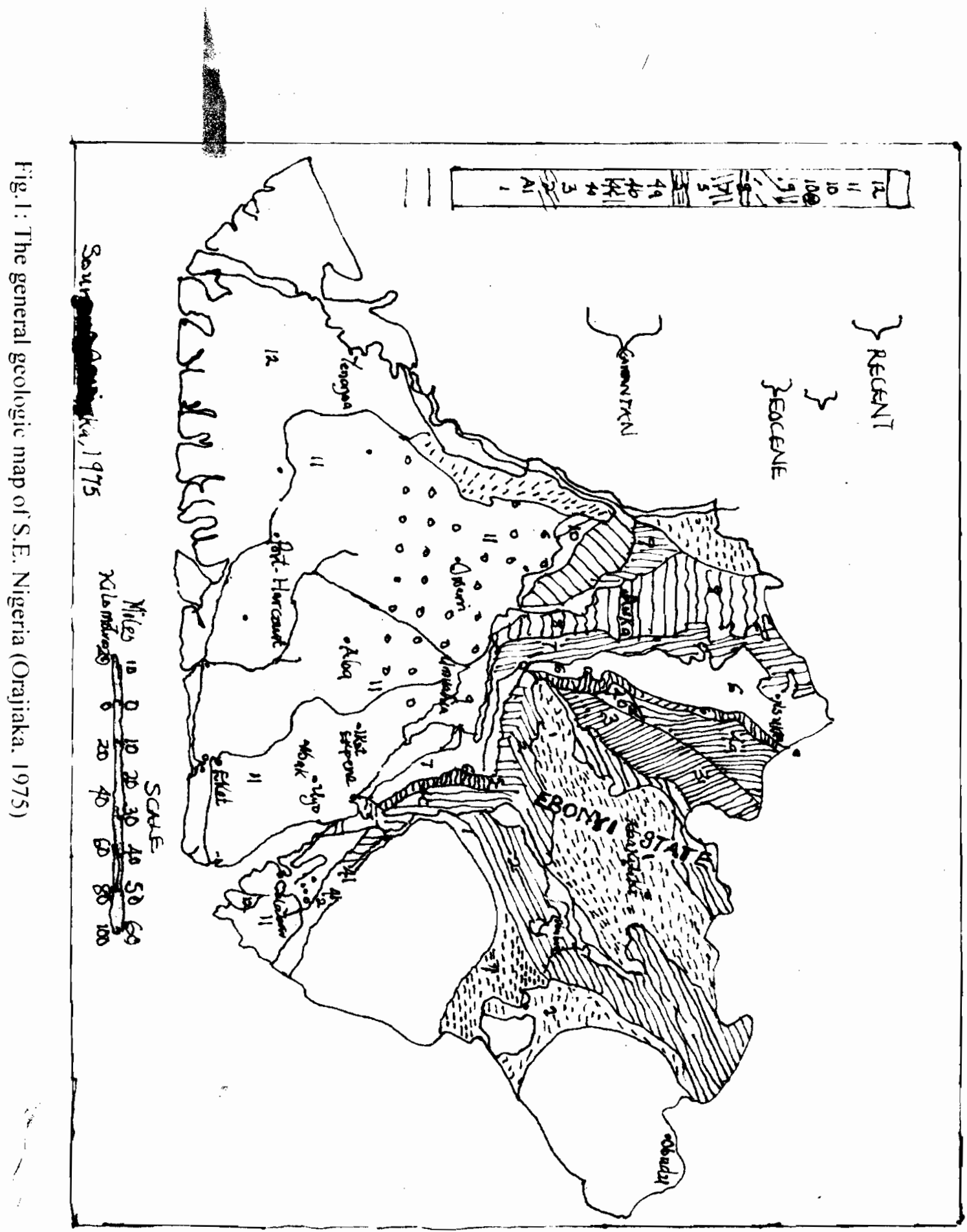




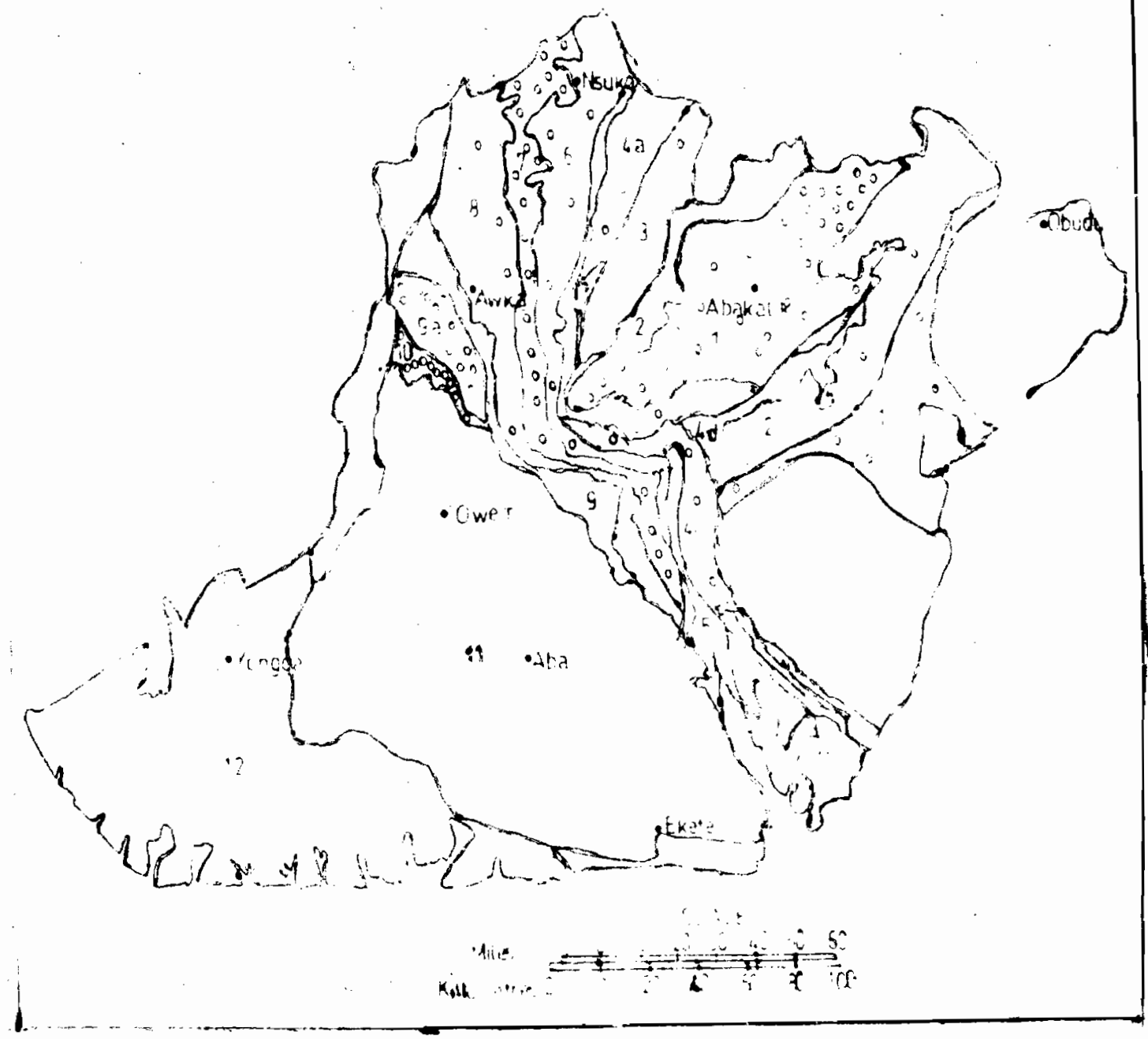

Fig. 2: showing the distribution of the farled borehoies in parts of Southeastern Nigeria

\section{AQUIFER ENVIRONMENT}

There is a serious and abject lack of knowledge and poor understanding of the hydrogeologic environment by various stakeholders who prospect for water supplies from groundwater domains. As a result, there are debilitating and destructive attitudes akin to the "bull-ina-china-shop mentality" in the way and manner people extract water from subsurface water sources. Groundwater in aquifers occurs under water table and hydrogeologic conditions from where water may be tapped for domestic or industrial uses from shallow or deep boreholes. The shallow boreholes in watertable aquifers may be dug manually or through other methods. During the archaeological times of the Egyptians, Indians, Greeks, Romans, Babylonians etc wells could be dug manually and were well-reinforced and concrete-lined to great depths such that such wells lasted for hundreds of years Some of such wells, tunnels and dugouts exist up till today But in modern times, such deep wells or boreholes that tap huge volumes of water from thick watertable or confined aquifers are drilled and protectively-lined with metal/steel casings to enhance their lives-longevity. Manually-drilled wells easily-fail through cave-ins, collapsing or slumping of the well-walls because of lack of casing or properly-protected cementation. Most of such well hardly-last or survive for up to five years or less Their waters are also easily-polluted or contamınated During the planning and design of such deep wells or boreholes, a great deal of hydrogeologic factors must be critically-investigated, appreciated and well-understood The elements of the environment may inciude proper Geomorphic. Geologic, Geophysical and Geochemical exploration methods and aquifer characteristics. The findings would assist in establishing appropriate drilling techniques to be employed; depth of aquifer to be maximally-penetrated: types of materiats used such as screen-type, gravel-packing etc : duration of pumping test and water analyses etc. The aquifer characteristics and parameters of depth. thickness, grainsize porosity, permeability, transmissivity. storativity. chemistry etc would be established before the well or borehole is completed and properly- 
developed. If these procedures are holistically-followed and implemented, the potentials for borehole failures and the emergency of allied hydrogeologic and socioeconomic problems will automatically-be reduced and minimized while its life-longevity will be enhanced. Unfortunately, as a result of obvious lack of expertise, ignorance or lack of adequate funding, these muchneeded hydrogeologic processes are hardly-carried out, thereby, resulting in the massive failures of many boreholes in southeastern Nigeria. Table 1 show problems identified at the different geologic terrains of Southeastern Nigeria.

Table 1: Problems identified at different geologic terrains of Southeastern Nigeria

\begin{tabular}{|c|c|c|}
\hline $\begin{array}{l}\text { Geologic } \\
\text { Terrain }\end{array}$ & \begin{tabular}{|l|} 
Borehole \\
Failure Rate
\end{tabular} & Problems identified \\
\hline $\begin{array}{l}\text { Ogwashi/Asaba } \\
\text { Formation }\end{array}$ & 33 & $\begin{array}{l}\text { (1) Loss circulation of drilling fluid } \\
\text { (2) Lack of detailed geophysical information }\end{array}$ \\
\hline Nanka Sand & 51 & $\begin{array}{l}\text { (1) Lack of appropriate expertise } \\
\text { (2) Poor financial resources and corruption } \\
\text { (3) Poor planning and lack of foresight }\end{array}$ \\
\hline Imo Shale & 14 & Lack of groundwater studies and evaluation \\
\hline $\begin{array}{l}\text { Nsukka } \\
\text { Formation }\end{array}$ & 112 & (1) Lack of groundwater studies and evaluatio \\
\hline $\begin{array}{l}\text { Ajalli } \\
\text { Sandstone }\end{array}$ & 24 & $\begin{array}{l}\text { (1) Lack of groundwater studies and evaluation } \\
\text { (2) Poor planning and lack of foresight } \\
\text { (3) Bad technology and service delivery } \\
\text { (4) Lack of appropriate expertise }\end{array}$ \\
\hline $\begin{array}{l}\text { Nkporo, Enugu } \\
\text { and Awgu } \\
\text { Shale }\end{array}$ & 32 & Lack of groundwater studies and evaluation \\
\hline $\begin{array}{l}\text { Afikpo } \\
\text { Sandstone }\end{array}$ & 11 & $\begin{array}{l}\text { (1) Lack of groundwater studies and evaluation } \\
\text { (2) Bad technology and service delivery } \\
\text { (3) Lack of appropriate expertise }\end{array}$ \\
\hline $\begin{array}{l}\text { Asu-River } \\
\text { Group }\end{array}$ & 191 & $\begin{array}{l}\text { (1) Lack of groundwater studies and evaluation } \\
\text { (2) Bad technology and service delivery } \\
\text { (3) Lack of appropriate expertise }\end{array}$ \\
\hline
\end{tabular}

\section{PRE-SYN-CONSTRUCTION FAILURES}

The Pre syn Construction failures occur before/during planning, drilling and construction of boreholes. Some of the causative factors for borehole failures that may be encountered include:

(a) Poor Groundwater Studies and Evaluation Water borehole construction is a cost intensive venture that must be carried out in such a manner that guarantees success. Of important before borehole drilling, is sufficient information on groundwater availability. Oftentimes boreholes are sited without sufficient hydrogeologic and geophysical studies. In areas where groundwater flow is controlled by fractures, good knowledge of the fracture trends and coefficient of anisotropy is required to locate areas of better groundwater development. In Abakaliki area for instance, most of the borehole are failing as a result of drilling site chosen outside the areas of fracturing. This type of difficulty can be resolved by proper geophysical studies. Most other terrain challenges can also be established before choosing drill sites through geological and hydrogeological studies.

Geophysical surveys can easily-detect weathered, faulted or fractured zones with aquifer high flow potential; detect vertical and horizontal fractured areas; define rock geometry and composition; define the profile of saltwater-freshwater boundary in coastal aquifers and define the thickness of weathered layers and the altitude and performance of the watertable aquifers
(Reynolds, 1998). Some of the failed boreholes in Nigeria can be attributed to a result of imperfect identification of aquifer layers for proper casing and screen placement(s) or projection. Boreholes that were logged after drilling. particularly, in a sedimentary terrain where drilling is by fluid circulation, have shown higher success rate. The logging of a borehole just after drilling may make the difference between a successful and productive borehole and a serious problem to handle with that may implicate well cementation or even in the most extreme cases, borehole failure and abandoning. Logging survey is, very important to the borehole industry.

\section{(b) Poor Planning and Lack of Foresight}

Poor planning and lack of foresight for a project applies only too often when drilling boreholes. Many borehole projects have collapsed as a result of problem of loss of circulation of drilling fluids to formations and other similar on-site associated challenges. A mud loss into the aquifer occurs suddenly and is, sometimes, severe to the degree that the mud level in the borehole can drop to induce caving through release of hydrostatic pressure. Areas where such difficult situations have been encountered in the southeastern Nigena include: Enugwu Ezike, Opi Nsukka, Egbema, Ozubulu, Udi, Oji River etc. These areas have predominantly poorlycemented sand found at shallow depths and are often extremely permeable and fluids they contain have abnormal earth pressure. The openings between the solid particles of the sands are in most cases larger than 
the largest solid particles in the mud, hence, the pores suck in the whole mud. Had this type of drilling challenge been reviewed with effective contingency plan put in place to correct the abnormal pressure problem should it occur, the programme would have allowed for options if fluids, somehow, were released from the bore path. In this way, the crew would have acted immediately when they encountered the problem. For those abnormally pressured sites, drillers had challenges they did not have contingency plans to control the fluid loss. Some of the boreholes at those areas failed, additional costs and time were lost and reputation of contractors was damaged. It is better to have more equipment and materials on site and not need then eventually than being unprepared and waste valuable time, money and reputation in the drilling process when failure occurs. In most cases, boreholes that are cased at wrong screen position(s) show poor performance with consequent failure effects

\section{(c) Bad Technology and Service Delivery}

Success in borehole drilling requires the use of the right technology, equipment and people if the attendant failure rate is to be averted. After a decision is made to drill a borehole, success is measured by the ability to overcome the challenges at the site to finish the job quickly and efficiently in a record time. First and foremost, one must engage a crew that can be depended upon for safe and cost-effective operations. Engaging a crew that cannot meet the expertise and needs of the borehole constructions, particularly. drilling and installation through difficult formations such as unconsolidated overburden, gravel, cobbles and sand, are at the forefront of the factors that have given way to high rate of borehole failures in Nigeria. The difficulties associated with retracting of drill bit from the casing in a heaving formation with an under-reaming systems and the inability to drill boreholes that are absolutely straight as results of instability effect achieved by rotation, all hinge on poor product and service delivery. The engagement of quack water-professionals in borehole construction cannot meet borehole integrity and should, therefore, be discouraged. Poor borehole constructions through bad technology and service delivery, results in faulty conditions of the casing and screen connections. leading to cracks or pull-apart of screens/casings and subsequent heavy pumping of sands or silt into the borehole and eventual failure.

(d) Lack of Appropriate Expertise

Many people that prospect for and exploit water from aquifers severely-lack the training and expertise for proper groundwater citing, evaluation, extraction and management. They may be Geologists who ought to know better, Civil Engineers, Geophysicists, outright "water quacks or water witches etc". They do not have the appropriate hydrogeologic training in order to understand and appreciate the groundwater flow regime and aquifer characteristics. As a result of the exigencies in lack of adequate potable water supplies or because of the financial gains that may accrue to the water exploiters, this non-water -knowledgeable persons freely-indulge themselves in witdcat borehole driltıng and water extracting. Their untoward acts precipitate large scale failure of boreholes and wastage of huge financial resources.

(e) Poor Financial Resources and Corruption Exploration, exploitation and management of aquifers for durable groundwater supplies are cost-intensive exercises that must be cost-effective in order to be longlasting and enduring. Acceptable and manageable financial outlays are required in order to establish a groundwater borehole that would be useful in terms of providing enough and safe well yields that should last for a long time. Many a time, funds available may not be enough or may be fraudulently-shortchanged along the away such that enough funds are not actually-provided for the execution of the project. As a result, a shady borehole product that may be embellished with corruption is the outcome. Such a fraudulent-executed project may fail after a short period of use.

\section{POST CONSTRUCTION BOREHOLE FAILURES}

These modes of borehole failures are predominantlycaused by man-made factors through their anthropogenic activities that may include:

(a) Groundwater Deficit by Over-pumping Understanding water budgets and how they change in response to human activities is an important aspect of groundwater hydrology, the development of a groundwater system is considered to be "safe" if the rate of groundwater withdrawal does not exceed the rate of recharge. Boreholes have limited production capacity. and in relative terms, there are some boreholes that approach unlimited performance. Ofteri times, boreholes are over exploited beyond their production capacities. This is peculiar to weathered layers. fractured shale or hard-rock terrains such as Abakaliki and some parts of Southwestern and Northern Nigeria. Most boreholes in these areas were functional at the time of construction but as production exceeded recharge some began to fail due to imbalance in water budget equilibrium. Borehole production capacity can be measured by pump test pumping water out of the borehole at varying flow rates, and measuring how the water level in the borehole is affected over time. When testing the total performance of a borehole. it is necessary to test the borehole to its limits. This is done at various increasing flow rates until the borehole can no longer support the pumping rate. Additionally, it is necessary to stop at each flow rate long enough for the water leve! in the borehole to stabilize before moving to the next flow rate If you have a large enough pump, a point will be reached where the water level does not stabilize. but keeps dropping, at which point you have exceeded the production capability of the borehole. Taking time to pump test a new borehole and develop a borehole curve can go a long way towards providing the most sultable pump adequate for the production capacity of the borehole (Robert 2005). This will reduce underground water mining deficit or failure of the borehole Pumping water out of a borehole. at varying flow rates and measuring how water level in the borehole is affected over time is an accurate way to measure a borehole performance 
Table 1: Drawdown table for a pumped borehole at Ninth Mile Corner Nowo, Enugu State.

\begin{tabular}{|c|c|c|c|c|c|}
\hline $\begin{array}{l}\text { Elapeed Time } \\
\text { (minutes) }\end{array}$ & Clock Time & $\begin{array}{l}\text { Water } \\
\text { Depth(m) }\end{array}$ & $\begin{array}{l}\text { Flow } \\
\text { Rate(litres per } \\
\text { minute) } \\
\end{array}$ & $\begin{array}{l}\text { Drawdown } \\
\text { (m) }\end{array}$ & $\begin{array}{l}\text { Water } \\
\text { Colour/Quality }\end{array}$ \\
\hline 0 & $8: 30 \mathrm{am}$ & $32.0(S W L)$ & 0 & 0 & \\
\hline 5 & 8:35am & 32.5 & 399 & 0.6 & $\begin{array}{l}\text { Muddy-dark } \\
\text { brown }\end{array}$ \\
\hline 10 & $8: 40 \mathrm{am}$ & 33.0 & 547 & 1.2 & $\begin{array}{l}\text { Muddy-dark } \\
\text { brown }\end{array}$ \\
\hline 15 & $8: 45 \mathrm{am}$ & 33.5 & 695 & 1.8 & $\begin{array}{l}\text { Muddy-dark } \\
\text { brown }\end{array}$ \\
\hline 20 & 8:50am & 34.0 & 844 & 2.4 & $\begin{array}{l}\text { Muddy-dark } \\
\text { brown }\end{array}$ \\
\hline 30 & 9:00am & 35.0 & 892 & 3.0 & $\begin{array}{l}\text { Muddy-dark } \\
\text { brown }\end{array}$ \\
\hline 40 & 9:10am & 36.5 & $114 \overline{40}$ & 3.6 & $\begin{array}{l}\text { Muddy-light } \\
\text { brown }\end{array}$ \\
\hline 50 & $9: 20 \mathrm{am}$ & 36.0 & 1286 & $4 . \overline{5}$ & Light brown \\
\hline 60 & 9:30am & 37.0 & 1436 & 5.5 & Lioht brown \\
\hline 90 & 10:00am & 38.0 & 1585 & 6.4 & Light brown \\
\hline 120 & $10: 30 \mathrm{em}$ & 39.0 & 1585 & 7.2 & $\begin{array}{l}\text { Clear-some } \\
\text { silt }\end{array}$ \\
\hline 150 & 11:00am & 40.0 & 1585 & 7.8 & $\begin{array}{l}\text { Clear-some } \\
\text { silt }\end{array}$ \\
\hline 180 & 11:30am & 40.0 & 1585 & 8.2 & Clear \\
\hline 210 & $12: 00 \mathrm{pm}$ & 40.6 & 1585 & 8.8 & Cloap \\
\hline 240 & $12: 30 \mathrm{pm}$ & 40.6 & 1585 & 8.8 & Clear \\
\hline 270 & $1: 00 \mathrm{pm}$ & 40.6 & 1585 & 8.8 & Clear \\
\hline 300 & 1:30 pm & 40.6 & 1585 & 8,8 & Clear \\
\hline
\end{tabular}

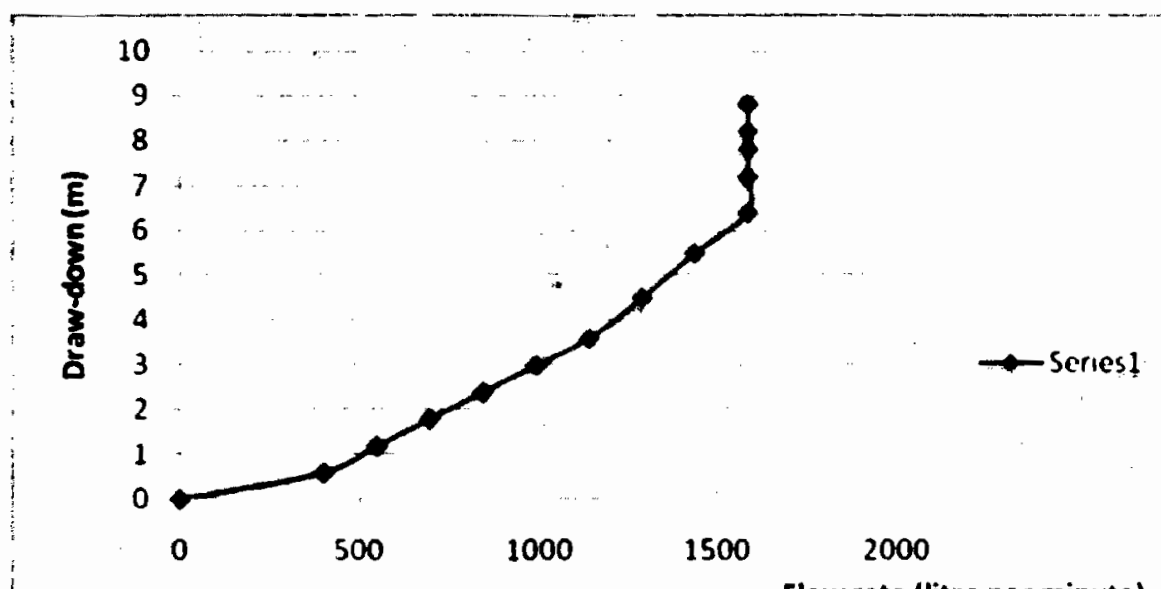

Figure 3 Borehole performance curve

Flow rate (litre per minute)

Fig. 3: shows the curve generated from the pump test data. From the curve, at 1585 litres per minute, the water level in the borehole continues to drawdown, indicating that the production capacity of the borehole has been exceeded.

(b) Wrong Placement of Casing and Gravel packing.

As a result of poor expertise in the drilling technology applied, a drilled borehole may be slightly-bent or be inclined such that the casing and screen become most difficult to emplace or install. Also, sometimes, the required grainsize for graveis is not used and the gravel packing technique is wrongly-executed. These will cause a short life for and quick failure of such a borehole. (c) Absence of Or Incomplete pumping test and data analysis

In a developing environment such as the southeast of Nigeria, pumping test of boreholes and pumping test analysis of the aquifer flow regime are hardily-evercarried out. In situations where pumping test analysis is done, the pumping woll is also usually-based as the observation well. This is not good enough. In a situation where there is/are no independent monitoring well(s) serving as observation mill(s). the derived aquifer perametors are not as useful and conctusive as they 
should be when computing the relevant data for the evaluation of the aquifer. Wrong evaluation results may result in a well failure.

(d) Corrosion and Corrosion of woll-Screen

Improper pumping and development techniques may result in sharp and destructive actions of sands on the screens whereby they may be adversely-scratched and defaced

by the corroding sands. This causes eventual destruction of the pore spaces of the screens thereby affecting porosity and inflows from the aquifer into the borehole. This corrosion of screens may eventually reduce the well-yield. Similarly, aggressive groundwater that may be acidic or alkaline in water quality may attack the screens and gravel pack through some oxidation/reduction reactions, thereby, destroying them after some time. Proper emplacement of gravel packing and full well development should be carried out to prevent corrosion is advised. Also water quality analysis must be carried out during developiment to know the chemistry of the groundwater and appropriate treatment carried out to prevent well failure.

(e) Role of Water Quacks and Witches

There are outright water quacks and witches who drill wildcat and unscientifically sited boreholes at anywhere and any place. In similar manner, boreholes are drilled and installed. These quacks have no training or scientific knowledge on aquifer geometry, exploitation and management. Their drive is revenue from water sales or supplies. They hardly succeed in their borehole commercial ventures on the long run as the well failures may be immediate or occur after a few yesis of poor service.

\section{(f) Mechanical Obstructions of Wells}

Plugging of boreholes by silts, clays or other particulate media entering the filter pack-either from the formation or through the top of the borehole-usually is difficult to determine except as indicated by periodic pumping tests. If yield is low, rehabilitation of the borehole is in order. Mechanical redevelopment of the borehole similar to that used to develop a new borehole should be the first step. Pumping the borehole at the highest rate attainable generally is advantageous. Surging and the use of horizontal jetting devices also may produce beneficial result

\section{REHABILITATION OF BOREHOLES}

A decrease in borehole discharges with time for similar surface stages with rising piezometric levels between boreholes is usually-indicative of decreasing efficiency. A quantitative measure of the loss in efficiency is determined by carefully conducting pumping test analysis. Should the pumping tests indicate a reduction in specific capacity of more than $20 \%$ compared to that measured at installation, a detailed study should be made of the consequences of the reduction and what remedial measures should be employed. Generally, it may be possible to restore the boreholes to about their original efficiency by means of rehabilitation techniques using different treatment options. As clogging of well screens and filter materials are caused only by the organic material produced by the attacking oxidation- reduction involved bacteria but also by oxides and hydroxides or iron and manganese, better results are usually obtained by treating the borehole alternately with a chlorine compound to attack the organic material deposits. Between each treatment. the borehole is pumped to waste to ensure that chlorine and remnant acids are not left in the borehole at the same time. Recommended measures using the procedures include:

a. Inject a mixture of acid, inhibitor and wetting agent. The addition of a chelating agent such as hydroxyactic acid may, sometimes, be beneficial. An inhibitor is needed only if the borehole screen is metallic. The amount of acid typically-used should be one-and-a-half to two times the volume of the borehole screen. If a chelating agent is not used. iron will precipitate out if the $\mathrm{pH}$ rises above 3. The precipitate can result in clogging: therefore. the $\mathrm{pH}$ should be monitored throughout the acid treatment and not be allowed to rise above 3 , regardless of whether or not a chelating agent is used

b. Gently agitate the solution with a jetting tool at 10 minutes intervals for a period of one to two hours.

c. Pump out a volume of solution equal to the volume of the borehole

d. Determine the $\mathrm{pH}$ of solution removed from the borehole. If the $\mathrm{pH}$ is higher than 3 , repeat steps (a) to (c).

e. Allow the acid to remain in the borehole for a minimum of 12 hours and pump borehole water to waste.

f. Inject a mixture of chlorine and one or more chloric-stable surfactants (e.g. Detergents and wetting agents). The concentration of the chlorine should exceed 1,000ppm.

g. Gently agitate the solution with a jetting tool at 10-minutes intervals every two hours for the first eight hours; at eighthour intervals for at least 24 hours

h. Pump out a volume of solution equal to the volume of the borehole.

i. Determine the chiorine concentration; if the concentration is less than $10 \%$ of the original concentration, repeat steps (f) to (h)

j. Perform a pumping test on the borehole. If the specific capacity has improved by more than $5 \%$, repeat the entire procedure until the specific capacity does not improve by $5 \%$ (Source: U.S Army corps of Engineers 2005)

\section{SUGGESTIONS AND RECOMMENDATIONS}

i. Drilling rigs must be positioned in such a way that zero level of platiorm is established to ensure that a straight borehole is drilled. 
ii. Drill with foresight and a plan to save time, reduce failure, increase efficiency and reduce cost.

iii. Drill borehole diameter large enough to freely accommodate the casing and screen sizes specific for the boreholes.

iv. Provide appropriate size of screen for the aquifer, to allow free flow of water into the borehole, with least resistance and minimal encrustation (Offodile, 2002)

v. After the boreholes are drilled, grouting should take the centre stage to avoid screen and casing separation or pull-apart by hanging.

vi. Determine the chemical characteristics of the water of the aquifer to determine before hand, its corrosive characteristics and make necessary allowance for an appropriate water quality treatment and in the choice of size and type of screen (Offodile, 2002).

vii. Avoid the high pressure jetting technique of development for shallow boreholes cased with PVC pipes since only forces of adhesion hold the cased joints. Generally, ensure proper coupling and tight connections of casing and screens before development to avoid pull-apart.

viii. Determine and install appropriate and suitable pumps accurate enough for borehole performance capacity to avoid water budget deficit and failure.

ix. Adopt a sustainable and enduring maintenance or cleaning culture for every borehole.

$x$ Feasible water projects must consider people and public participation in the entire project planning and execution; and incorporate local cultures, needs, customs, norms to increase people's participation at all levels.

xi. Above all, appropriate expertise and right caliber of manpower must be employed in planning and execution of the entire project. Every effort should be made to provide enough funds and honestly use all the provided resources devoid of fraud and corruption of any type in carrying out the exercise.

\section{ACKNOWLEDGEMENTS}

The authors are grateful to the Ebonyi State Univegrsity and the Nnamdi Azikiwe University. Nigeria for the financial and logistic support they provided during the research.

\section{REFERENCES}

Egboka, B. C. E, 1999. The Hydrogeologic (Water) Cycle: A Sustainable Holism of TechnologicalCum-Socioeconomic Environment. An Inaugural Lecture presented to the Nnamdi-Azikiwe University, Awka, Anambra State, Nigeria, 46p.

Offodile, M. E., 2002. Groundwater Studies and Development in Nigeria, second edition. Mecon Geology and Engineering Services Limited, Jos, Nigeria, pp.365.

Reynolds, J. M., 1998. Groundwater potential. An Introduction to Applied and Environmental Geophysics, second edition, Wiley. Limited, West Susssex, England, pp.476-478.

Robert, P., 2005. Well Curves; The Fundamentals of pumped water systems, NATIONAL DRILLERS 26(9): $10-11$

Orajaka, S. O., 1975. Saltwater resources of East Central State of Nigeria. Journal of Mining and Geology. 1: $35-41$. 